\title{
JNVESTJGHACJÓN
}

\section{Extraction of oil from pequi fruit (Caryocar Brasiliense, Camb.) using several solvents and their mixtures}

\author{
By L.P. Aquino, ${ }^{a}$ S.V. Borges, ${ }^{a}$ F. Queiroz, ${ }^{a, *}$ R. Antoniassi ${ }^{b}$ and M. A. Cirillo ${ }^{c}$ \\ ${ }^{a}$ Depto. de Ciência dos Alimentos - Universidade Federal de Lavras. Campus Universitário, \\ Caixa Postal 3037. CEP 37200-000. Lavras-MG. Brasil. \\ ${ }^{\mathrm{b}}$ Embrapa Agroindústria de Alimentos - Laboratório de Óleos e Gorduras. Rio de Janeiro-RJ. Brasil. \\ ${ }^{c}$ Depto. de Ciencias Exactas - Universidade Federal de Lavras. Campus Universitário, Lavras-MG. Brasil. \\ ( ${ }^{*}$ Corresponding author: fqueiroz@dca.ufla.br)
}

\section{RESUMEN}

Extracción de aceite del fruto pequi (Caryocar Brasiliense, Camb.) utilizando diversos disolventes y sus mezclas

En este trabajo fue estudiado el proceso de extracción de aceite de la pulpa de pequi utilizando diferentes disolventes (n-hexano, acetona y etanol) y sus mezclas, empleando diseño central simplex. Las extracciones fueron realizadas a $50^{\circ} \mathrm{C}$, durante 16 horas de agitación $(22 \mathrm{~Hz})$. La proporción sólido:líquido empleada fue 1:10 (p/p). Los mayores rendimientos fueron obtenidos para las extracciones con acetona y con hexano, especialmente cuando fueron mezclados con etanol. El índice de yodo, el índice de saponificación y el índice de refracción no difirieron significativamente entre los tratamientos. Los mayores valores de acidez se obtuvieron en la extracción con etanol. Los mayores contenidos en carotenoides se obtuvieron en las extracciones con acetona y etanol como disolventes puros. El perfil de los ácidos grasos en las fracciones de aceite de los extractos no presentó variación entre los diferentes tipos de disolventes y sus mezclas.

PALABRAS CLAVE: Extracción sólido-líquido - Extracto de Pequi - Regla de mezclas

\section{SUMMARY}

Extraction of oil from pequi fruit (Caryocar Brasiliense, Camb.) using several solvents and their mixtures

In this study, the oil extraction process from pequi pulp using different solvents (hexane, acetone and ethyl alcohol) and their mixtures was investigated, using a simplex-centroid design. The extraction occurred at $50^{\circ} \mathrm{C}$, under stirring $(22 \mathrm{~Hz})$, for 16 hours. The solid-liquid ratio used was 1:10 (w/w). Higher yield values were obtained for extractions with acetone and hexane, especially their mixtures with ethanol. lodine value, saponification value and refractive index did not differ significantly among the treatments. A higher acid value was obtained for the extraction with ethyl alcohol. Higher carotenoid contents were obtained for the extraction with acetone and ethyl alcohol as pure solvents. The fatty acid profile in the oil fraction of the extracts did not vary among the different types of solvents and their mixtures.

KEY-WORDS: Mixing rule - Pequi extract - Solid-liquid extraction.

\section{INTRODUCTION}

Pequi (Caryocar brasiliense) is an oil-rich fruit cultivated in the Brazilian cerrado savanna and despite being little explored by the processing industry, it has many applications in the food, medicine and cosmetic industries as it is particularly rich in carotenoids and oleic and palmitic fatty acids (Silva et al., 1993; Facioli and Gonçalves, 1998; Azevedo-Meleiro and Rodriguez-Amaya, 2004; Lima et al., 2007).

Organic solvents are widely used as a technique to extract oil (solid-liquid extraction), as authorized by the Committee on Food Chemicals Codex (1996), including acetone, ethanol and hexane; and they must be eliminated in the final stage of processing.

Water can also be used for the extraction of pequi oil and indeed it is used in small-scale production (Facioli and Gonçalves, 1998). However, it produces a low yield besides the high risk of microbiological contamination and the use of high temperatures that can degrade compounds of nutraceutical interest, including carotenoids (AbuArabi et al., 2000).

Hexane is the most commonly used solvent in solid-liquid extraction, especially in the vegetal oil industry, due to its strong affinity with oils and fats and to its easy recovery (low vaporization temperature). However, other solvents, especially polar solvents, have been investigated as potential substitutes for hexane, a petroleum by-product that can potentially cause cancer. Studies have been performed by various authors (Kim and Yoon, 1990; Abu-Arabi et al., 2000; Lalas and Tsaknis, 2002; 
Dunford and Zhang, 2003; Abdulkarim et al., 2005) on the effect of extraction using different solvents and their mixtures on the yield and quality of oil, obtaining extracts with different components other than fatty acids, such as antioxidants, pigments, proteins and others. Different compositions may or may not affect the characteristics of the lipid extract (Moreno et al., 2003, Dunford and Zhang, 2003).

The objective of this work is to evaluate the effect of using different types of solvent (hexane, acetone and ethyl alcohol) and their mixtures on the yield of pequi extract, physico-chemical characteristics, fatty acid composition and the total carotenoid content of the pequi extract.

\section{MATERIALS AND METHODS}

\subsection{Materials}

The pequi samples (Caryocar brasiliense Camb.) used in this study were obtained in the municipality of Cordisburgo, Minas Gerais state, during the harvest season of January 2006. Only undamaged ripe samples were selected.

\subsection{Sample preparation}

The pequi samples were washed under running water and immersed in a solution of sodium hypochlorite at $50 \mathrm{mg} / \mathrm{kg}$ for five minutes, then peeled. They were pulped manually with a stainless steel knife, then cut into slivers $0.3 \mathrm{~cm}$ thick, $0.5 \mathrm{~cm}$ wide and $1.5 \mathrm{~cm}$ long and frozen in plastic bags. The frozen pulp was dried in a Fanem incubator at $40^{\circ} \mathrm{C}$ for 19 hours according to previously optimized results (Aquino et al., 2006). Next it was crushed in a Britania multiprocessor for 1 minute and the granulometry was determined using Granutest Tyler sieves $9(2.00 \mathrm{~mm}), 20(0.85 \mathrm{~mm})$ and $60(0.25$ $\mathrm{mm}$ ), for 10 minutes. The experiment used samples presenting Tyler granulometry of between 9 and 20 .

\subsection{Experimental design}

The experimental design was entirely randomized, with two replicates for each variable studied, except for yield, which used six replicates. The treatments were based on the mixing rule using a simplexcentroid design for three components (Cornell, 2002). The treatments are specified in Table 1.

The extracts obtained from different treatments were confronted with a control sample obtained at the central market of Belo Horizonte (Minas Gerais state, Brazil), with the determination of acid value, refractive index, total carotenoid content and fatty acid composition being verified if the values of the control sample were inside of the limits of the values obtained for the treatments with organic solvents and mixtures. The iodine value and saponification value were calculated based on the fatty acid composition. The extraction of oil from the control sample used hot water as solvent.
Table 1

Statistical design of the mixtures with the levels of variables used in the simplex-centroid design

\begin{tabular}{cccc}
\hline \multirow{2}{*}{ Test } & \multicolumn{3}{c}{ Proportion $^{\mathrm{a}}$} \\
\cline { 2 - 4 } & $\mathbf{X}_{1}$ & $\mathbf{X}_{2}$ & $\mathbf{X}_{3}$ \\
\hline T1 & 1 & 0 & 0 \\
T2 & 0 & 1 & 0 \\
T3 & 0 & 0 & 1 \\
T4 & $1 / 2$ & $1 / 2$ & 0 \\
T5 & $1 / 2$ & 0 & $1 / 2$ \\
T6 & 0 & $1 / 2$ & $1 / 2$ \\
T7 & $1 / 3$ & $1 / 3$ & $1 / 3$ \\
\hline${ }^{a} \mathrm{X}_{1}:$ mass fraction of hexane; $X_{2}:$ mass fraction of acetone; \\
$X_{3}$ : mass fraction of ethyl alcohol.
\end{tabular}

\subsection{Extraction of oil}

Extraction was performed in a Marconi (MA830/A) cooling incubator-shaker. The pequi sample and solvent were placed in a previously tared $250 \mathrm{~mL}$ Pyrex ${ }^{\circledR}$ flask (N:4100J24/40) with a ground-glass cap. During the extraction process, the controlled variables were temperature $\left(50^{\circ} \mathrm{C}\right)$, stirring $(22 \mathrm{~Hz})$, time (16 hours) and solid-liquid ratio at 1:10 (w/w). The time to achieve a practical equilibrium was 16 hours according to preliminary tests. A temperature of $50^{\circ} \mathrm{C}$ was selected for the extraction process as it is lower than the usual boiling temperatures of solvents (acetone, hexane and ethyl alcohol) used in this extraction stage.

After the extraction, the solution was vacuum filtered by a Primar pump (model 141, n.284, Type $2 \mathrm{VC}$, air displacement of $37 \mathrm{~L} / \mathrm{min}$ ) and the extract was collected into a previously tared $250 \mathrm{~mL}$ Pyrex ${ }^{\circledR}$ beaker and transferred to a vacuum oven at $65^{\circ} \mathrm{C}$ until the solvent evaporated (constant weight). The solute mass (oil) was determined by gravimetry and the yield was calculated based on the ratio between the amount of extract obtained and the sample initially placed in the extractor (dry basis).

\subsection{Physico-chemical analysis}

The AOCS (1997) official method was used for the determination of the acidity of the lipid extracts (method $\mathrm{Ca} 5 \mathrm{a} 40$ ). The refractive index (RI) was determined using an Abbé refractometer, according to the official method Cc 7-25 (AOCS, 1997).

\section{Analysis of fatty acid composition}

The fatty acid composition was determined by gas chromatography after derivatization to methyl esters. Methyl esters were prepared according to Hartman and Lago (1973) and analyzed by highresolution gas chromatography using an HP-5890 chromatograph with a cyanopropyl siloxane fused 
silica capillary column $(60 \mathrm{~m} \times 0.32 \mathrm{~mm} \times 0.25 \mu \mathrm{m})$, with a programmed temperature of $150^{\circ} \mathrm{C}$ to $200^{\circ} \mathrm{C}$, set to rise $1.3^{\circ} \mathrm{C} / \mathrm{min}$. Identification was made through comparison of the retention times with $\mathrm{Nu}$ Chek Inc. standards (Elysian, IL) and quantification used internal normalization. Based on fatty acid composition, the iodine value and saponification value were calculated according to official methods Cd 1c 85 and Cd 3a 94 (AOCS, 2004).

\section{Carotenoid content}

The total carotenoid content was analyzed by reading the samples, in the $452 \mathrm{~nm}$ visible spectrum, using spectrophotometric grade hexane as solvent. The calculation of total carotenoids was based on the extinction value of 2500 , as suggested by Davies (1976).

\subsection{Statistical analysis}

The response variables, oil yield, iodine value (IV), saponification value (SV), acidity, refractive index (RI) and carotenoid content, of each experiment were analyzed using the program Statistica (StatSoft Inc., 1999), with mixing rule analysis using a simplex-centroid design. An analysis of variance was applied to test the fit of the models. The validation of the models considered the significance of regression and lack of fit in relation to $90 \%$ confidence, and by the coefficient of determination $R^{2}$, an important evaluator of the predictive power of the models. In order to determine the effect of the independent variables on the responses evaluated, we constructed contour line graphs defined in the experimental area. The proposed model is thus illustrated in equation 1

$$
\begin{aligned}
& Y=a_{1} X_{1}+a_{2} X_{2}+a_{3} X_{3}+a_{12} X_{1} X_{2}+a_{13} X_{1} X_{3}+ \\
& +a_{23} X_{2} X_{3}+a_{123} X_{1} X_{2} X_{3}
\end{aligned}
$$

where $Y$ is the response variable for each type of treatment, $X_{1}$ is the mass fraction of hexane, $X_{2}$, of acetone, $X_{3}$, of ethyl alcohol, and $a_{i}(i=1,2,3)$, $a_{i j}(j=1,2,3$ and $i<j)$ and $a_{i j k}(k=1,2,3$ and $i<j<k)$ are the coefficients of regression. The coefficients $a_{i}\left(a_{1}, a_{2}\right.$ e $\left.a_{3}\right)$ represent the expected response to extraction with pure solvent. The second-order coefficients $a_{i j}$ describe the binary interactions between solvent pairs in the extraction process. A significant positive term of $\mathrm{a}_{\mathrm{ij}}$ in this model indicates that a solvent binary mixture extracts an excess of material than would be expected by simply averaging to value using each solvent separately. This excess is called synergism. The opposite of synergism ( $a_{i j}$ is negative) is called antagonism of the binary mixture. The coefficients $a_{i j k}$ will be important if ternary interactions among mixture solvents are important for the extraction process (Cornell, 2002; Garcia et al., 2010).

\section{RESULTS AND DISCUSSION}

Table 2 provides the coefficients of the quadratic equation $\mathrm{Q}$, (yield, iodine value, acidity, refractive index and carotenoid content) and cubic equation $\mathrm{C}$, (saponification value) of the experimental results for a simplex-centroid design, fitted to the model with the best fit.

Table 2

Results of fitted models for response variables: yield, iodine value (IV), acidity, refractive index (RI),

\begin{tabular}{|c|c|c|c|c|c|c|}
\hline & Yield & IV & SV & Acidity & $\mathbf{R I}$ & CC \\
\hline Model & Q & $Q$ & $\mathrm{C}$ & Q & $Q$ & $Q$ \\
\hline$R^{2}(\%)$ & 69.41 & 62.27 & 46.59 & 67.19 & 29.23 & 66.42 \\
\hline $\begin{array}{l}\text { Significance } \\
\text { of regression }\end{array}$ & $S$ & NS & NS & $S$ & NS & $S$ \\
\hline$a_{1}$ & $60.17 \pm 2.0$ & $49.19 \pm 0.49$ & $197.49 \pm 0.29$ & $1.54 \pm 0.97$ & $1.458 \pm 0.001$ & $199 \pm 16$ \\
\hline$a_{2}$ & $61.07 \pm 2.30$ & $50.15 \pm 0.49$ & $197.20 \pm 0.29$ & $1.75 \pm 0.97$ & $1.459 \pm 0.001$ & $300 \pm 16$ \\
\hline$a_{3}$ & $39.78 \pm 2.30$ & $51.34 \pm 0.49$ & $197.22 \pm 0.29$ & $4.00 \pm 0.97$ & $1.457 \pm 0.001$ & $296 \pm 16$ \\
\hline$a_{12}$ & $-29.98 \pm 10.61$ & $\begin{array}{c}0.39 \pm 2.23 \\
(\mathrm{NS})\end{array}$ & $\begin{array}{c}1.03 \pm 1.42 \\
(\mathrm{NS})\end{array}$ & $\begin{array}{c}4.00 \pm 4.45 \\
\text { (NS) }\end{array}$ & $\begin{array}{c}-0.0034 \pm .0046 \\
\text { (NS) }\end{array}$ & $\begin{array}{l}50 \pm 74 \\
(\mathrm{NS})\end{array}$ \\
\hline$a_{13}$ & $47.29 \pm 10.61$ & $\begin{array}{c}-2.01 \pm 2.23 \\
\text { (NS) }\end{array}$ & $\begin{array}{c}0.16 \pm 1.42 \\
(\mathrm{NS})\end{array}$ & $\begin{array}{c}-0.77 \pm 4.45 \\
\text { (NS) }\end{array}$ & $\begin{array}{c}-0.0014 \pm \\
0.0046(\mathrm{NS})\end{array}$ & $\begin{array}{l}50 \pm 74 \\
(\mathrm{NS})\end{array}$ \\
\hline$a_{23}$ & $53.75^{\star} \pm 10.61$ & $-5.41 \pm 2.23$ & $\begin{array}{c}1.15 \pm 1.42 \\
(\mathrm{NS})\end{array}$ & $\begin{array}{c}-3.17 \pm 4.45 \\
(\mathrm{NS})\end{array}$ & $\begin{array}{c}-0.0034 \pm \\
0.0046(\mathrm{NS})\end{array}$ & $\begin{array}{c}-151 \pm 74 \\
(\mathrm{NS})\end{array}$ \\
\hline$a_{123}$ & - & - & $\begin{array}{c}-21.78 \pm 9.97 \\
\text { (NS) }\end{array}$ & - & - & - \\
\hline
\end{tabular}
saponification value (SV) and carotenoid content ${ }^{a}$

\footnotetext{
${ }^{a}$ Q: quadratic model; C: cubic model; S: significant at $10 \%$ probability level; NS: not significant.
} 
The results in Table 2 indicate that the regression was significant only for the variables' yield, carotenoid content and acidity. Hence the construction of contour lines for these variables only, given that the significance of these models led us to reject the hypothesis that the coefficients are significantly different from zero. The statistically insignificant terms were kept in the model because the exclusion of these terms reduces the value of coefficient determination $R^{2}$. The analysis of variance for yield and carotenoid content is illustrated in Table 3 , where it can be noted that the quadratic model fit was significant $(P<0.1)$ and the lack of fit was not significant $(P>0.1)$, explaining $69.41 \%$ and $66.42 \%$ of variability in yield and carotenoid content, respectively. The analysis of variance for acidity (Table 4) indicates that the fitted model was significant $(P<0.1)$, the lack of fit was not significant and explains $67.19 \%$ of variability.

Figure 1 provides contour lines for yield, obtained from the quadratic model fit.

For treatments using pure solvents (Treatments T1, T2 and T3 - Table 1) the maximum yield was $61.07 \%$ with acetone (T2), followed by $60.17 \%$ with hexane (T1) while the lowest yield was obtained using ethyl alcohol (39.78\% - T3). From the model equation we observed a synergic effect of the solvents mixed with ethyl alcohol, with higher yields noted for $1: 1$ ratios of acetone-ethyl alcohol $(63.86 \%$
- T6) and hexane-ethyl alcohol (61.80\% - T5). The extract obtained using the acetone-hexane mixture also produced a good yield (53.13\% - T4), although we noted an antagonist interaction between hexane and acetone, since the value of $a_{12}$ coefficient is negative (Table 2).

The yield values using hexane, acetone and their mixtures with ethanol at a $1: 1$ ratio were higher than those found by Lima et al. (2007) in the extraction of pequi oil using petroleum ether as solvent $(57 \% \mathrm{db})$.

Franco et al. (2007) observed an increased solubility of rubiginosa rose oil in ethanol with a rise in temperature. According to the authors, although solubility increases with a rise in temperature, it will be higher in hexane, with a low solid: liquid ratio being required in the extraction with ethanol to obtain the same performance. Freitas and Lago (2007) reported that Freitas et al. (2001) had obtained higher yield values in the extraction of coffee and sunflower oil with ethanol at $70^{\circ} \mathrm{C}$ to $75^{\circ} \mathrm{C}$ (sample ratio for ethanol $1: 3$ ) in relation to the lipid fraction extracted using petroleum ether. According to these authors, the use of extraction temperatures above $70^{\circ} \mathrm{C}$ may have favored the removal of wax by ethanol. Chien et al. (1990) observed that the yield of corn oil in the extraction using ethanol increased with a rise in temperature. According to the above works and judging by the effect of temperature on the yield of extract using

Table 3

Analysis of variance of quadratic regression models for yield and carotenoid content

\begin{tabular}{lrrrrrrrr}
\hline \multirow{2}{*}{ Source } & \multicolumn{4}{c}{ Yield } & \multicolumn{4}{c}{ Carotenoid Content } \\
\cline { 2 - 9 } & \multicolumn{1}{c}{ SS } & \multicolumn{1}{c}{ DF } & MS & F & SS & DF & MS & F \\
\hline Regression & 2473.249 & 5 & 494.6499 & $15.46^{\mathrm{a}}$ & 9791.17 & 5 & 1958.233 & $3.76^{\mathrm{a}}$ \\
Residual & 1087.707 & 34 & 31.9914 & & 4169.39 & 8 & 521.174 & \\
Lack of fit & 11.858 & 1 & 11.8584 & 0.364 & 1024.01 & 1 & 1024.006 & 2.279 \\
Pure error & 1075.849 & 33 & 32.6015 & & 3145.38 & 7 & 449.341 & \\
Total & 3560.957 & 39 & 91.3066 & & 13960.56 & 13 & 1073.889 & \\
\hline
\end{tabular}

a Significant at the $10 \%$ probability level.

NS: not significant.

Table 4

Analysis of variance of the quadratic regression model for acidity

\begin{tabular}{lcrcc}
\hline \multirow{2}{*}{ Source } & \multicolumn{5}{c}{ Acidity } \\
\cline { 2 - 5 } & SS & DF & MS & F \\
\hline Regression & 31.01233 & 5 & 6.202466 & 3.28 \\
Residual & 15.14325 & 8 & 1.892906 & \\
Lack of fit & 0.12229 & 1 & 0.122288 & 0.057 \\
Pure error & 15.02096 & 7 & 2.145851 & $(\mathrm{NS})$ \\
Total & 46.15558 & 13 & 3.550429 & \\
\hline
\end{tabular}

* Significant at the $10 \%$ probability level.

NS: not significant. 


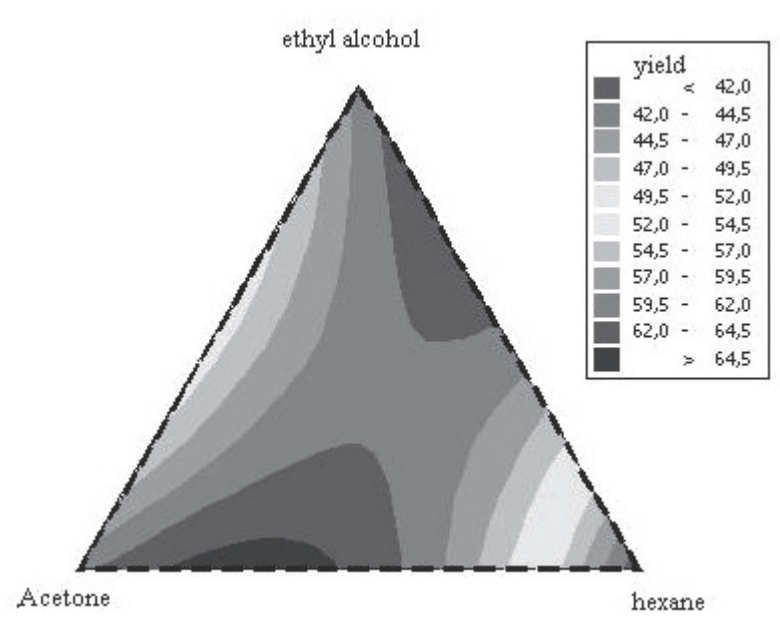

Figure 1

Contour line for extract yield (\% dry basis) in different treatments.

ethanol, we expect to obtain a higher yield of pequi oil with ethanol if we raise the temperature to values near $70^{\circ} \mathrm{C}$, yet under such condition the extract may present a different composition from that obtained in this work. That said, the use of ethanol as solvent in acetone and hexane mixtures is attractive to obtain pequi extract, due to the high expected yields, yet further studies should be done to investigate its feasibility as a pure solvent using higher temperatures. Franco et al. (2007) points to the advantage of using ethanol as a solvent in the extraction of oil due to it being a renewable fuel and due to the low solubility of oil in ethanol at low temperatures, facilitating the separation of oil from ethanol.

According to Lalas et al. (2002), higher yields of lipid extract were obtained from Moringa Olifera seeds using a mixture of polar solvents (1:1 chloroform-methanol) as opposed to the results with hexane. According to these authors, the extraction using polar solvents produced higher yields due to an increased ability of the polar solvent to overcome the forces that bind lipids within the sample matrix. Mani et al. (2007) studied the optimization of operating conditions (temperature, particle size, extraction time and solvent type) to extract oil from Moringa Olifera seed using hexane, petroleum ether and acetone as solvents. The extraction was performed using a Soxhlet apparatus, and the maximum yields were $33.1 \%$ for hexane, $31.8 \%$ for petroleum ether and $31.1 \%$ for acetone at a temperature of $60^{\circ} \mathrm{C}$.

Higher yields of lipid extract were obtained by mixing polar and non-polar solvents to obtain oil from Moringa Olifera seeds (Lalas et al., 2002). In their study on the solid-liquid extraction of jojoba oil using different solvents, Abu-Arabi et al. (2000) observed higher yields for hexane, petroleum ether and benzene than for chloroform (polar solvent), which, according to them, was due to the chemical nature of the oil being extracted.

The iodine value (IV) reflects the fatty acid composition of oils and fats as it measures the amount of unsaturation present in the oil. The proposed quadratic model presented a low correlation coefficient, with the lodine value not being affected by the use of different solvents (Table 2). Similar results were obtained by Lalas et al. (2002) for the extraction of oil from Moringa Olifera seeds using hexane, chloroform-methanol and cold pressing. This result was expected, since this analysis compares only the glyceride fraction present in the various extracts and it presents the same composition, regardless of the solvent used (Table 5). The iodine values were found to be between 49.19 and $51.34 \mathrm{~g}$ of iodine $/ 100 \mathrm{~g}$ of sample, which is close to the control sample results and results found by Facioli and Gonçalves (1998), that is, 50.69 and $50 \mathrm{~g}$ of iodine $/ 100 \mathrm{~g}$ of sample, respectively.

The saponification value (SV) shows the relative amount of high and low molecular weight fatty acids,

Table 5

Fatty acid composition of pequi oil (\%) in different treatments ${ }^{a}$

\begin{tabular}{cccccccccccccccccccc}
\hline & \multicolumn{1}{c}{ Saturated fatty acids } & \multicolumn{1}{c}{ Unsaturated fatty acids } \\
\cline { 2 - 5 } & C8:0 & C10:0 & C12:0 & C14:0 & C16:0 & C17:0 & C18:0 & C20:0 & C22:0 & C24:0 & C16:1 & C17:1 & C18:1 & C18:2 & C18:3 & C20:1 \\
\hline T1 & 0.05 & $\mathrm{~T}$ & $\mathrm{~T}$ & 0.09 & 41.55 & 0.11 & 2.52 & 0.19 & $\mathrm{~T}$ & $\mathrm{~T}$ & 1.11 & 0.10 & 52.90 & 1.10 & 0.24 & 0.15 \\
$\mathrm{~T} 2$ & 0.04 & $\mathrm{Nd}$ & $\mathrm{T}$ & 0.08 & 40.48 & 0.10 & 2.58 & 0.20 & $\mathrm{~T}$ & $\mathrm{~T}$ & 1.07 & $\mathrm{Nd}$ & 54.09 & 1.11 & 0.21 & 0.16 \\
$\mathrm{~T} 3$ & 0.05 & $\mathrm{Nd}$ & 0.04 & 0.08 & 39.64 & 0.09 & 2.28 & 0.18 & $\mathrm{~T}$ & $\mathrm{~T}$ & 1.09 & 0.10 & 54.79 & 1.32 & 0.29 & 0.17 \\
$\mathrm{~T} 4$ & $\mathrm{~T}$ & $\mathrm{Nd}$ & $\mathrm{T}$ & 0.18 & 40.87 & 0.10 & 2.52 & 0.20 & $\mathrm{~T}$ & $\mathrm{~T}$ & 1.10 & $\mathrm{Nd}$ & 53.50 & 1.13 & 0.27 & 0.17 \\
$\mathrm{~T} 5$ & 0.03 & $\mathrm{~T}$ & $\mathrm{~T}$ & 0.08 & 40.75 & 0.10 & 2.50 & 0.20 & $\mathrm{~T}$ & $\mathrm{~T}$ & 1.05 & 0.09 & 53.69 & 1.13 & 0.23 & 0.16 \\
$\mathrm{~T} 6$ & 0.05 & $\mathrm{~T}$ & $\mathrm{~T}$ & 0.09 & 41.41 & 0.10 & 2.41 & 0.20 & $\mathrm{~T}$ & $\mathrm{~T}$ & 1.05 & 0.09 & 53.17 & 1.12 & 0.26 & 0.17 \\
$\mathrm{~T} 7$ & 0.03 & $\mathrm{~T}$ & $\mathrm{~T}$ & 0.09 & 41.50 & 0.50 & 2.44 & 0.20 & $\mathrm{~T}$ & $\mathrm{~T}$ & 1.08 & 0.09 & 52.97 & 1.11 & 0.26 & 0.16 \\
$\mathrm{CS}$ & 0.04 & $\mathrm{~T}$ & $\mathrm{~T}$ & 0.10 & 40.71 & $\mathrm{~T}$ & 1.73 & 0.16 & $\mathrm{~T}$ & $\mathrm{~T}$ & 0.96 & 0.09 & 54.70 & 1.11 & 0.25 & 0.22 \\
\hline
\end{tabular}

\footnotetext{
${ }^{\mathrm{a}} \mathrm{T}=$ traces; $\mathrm{Nd}=$ not detected; $\mathrm{CS}=$ control sample.
} 
being inversely proportionate to the molecular weight of fatty acids present in triacylglycerols. The proposed model for this index presented low variation among treatments using different solvents and their mixtures; and so the quadratic fit was poor, leading us to conclude that the saponification value was not affected by the use of different solvents, with the approximate value being $197 \mathrm{mg}$ of $\mathrm{KOH} / \mathrm{g}$. The saponification value for the control sample was $197.23 \mathrm{mg}$ of $\mathrm{KOH} / \mathrm{g}$. Facioli and Gonçalves (1998) obtained similar iodine values for pequi oil (200 $\mathrm{mg}$ of $\mathrm{KOH} / \mathrm{g}$ ). In a study on the extraction of oil from avocado using different solvents, Moreno et al. (2003) obtained lower values using acetone. In the extraction of oil from Moringa seeds this index did not vary when hexane and chloroform-methanol were used as solvents (Lalas et al., 2002).

Acidity in oil results from enzymatic hydrolysis which in turn is related to the conservation state and humidity level of the raw material. When fruits have high humidity, hydrolytic enzymes (lipase) act rapidly on triacylglycerols, releasing free fatty acids.

Acidity presented a significant response variation in the treatment using ethyl alcohol, which is noticeable by the parameter estimates of the quadratic model fitted to the response variable acidity (Table 2) and by Figure 2, given that it is the most recommended solvent for the extraction of free fatty acids from oil because it is the most efficient. The levels obtained were in excess of $3.85 \%$ and this probably relates to the difficulty with which the oil-solvent solution separates, as the boiling temperature of alcohol is $78.4^{\circ} \mathrm{C}$; or maybe because ethanol dissolves more fatty acid. A higher acidity value was verified for oil extracts from avocado using acetone (Moreno et al., 2003).

The acidity of the control sample $(1.52 \%$ of oleic acid) revealed that extraction with water did not affect its conservation state, as with the extract obtained with hexane $(1.54 \%$ of oleic acid). Facioli and Gonçalves (1998) obtained a

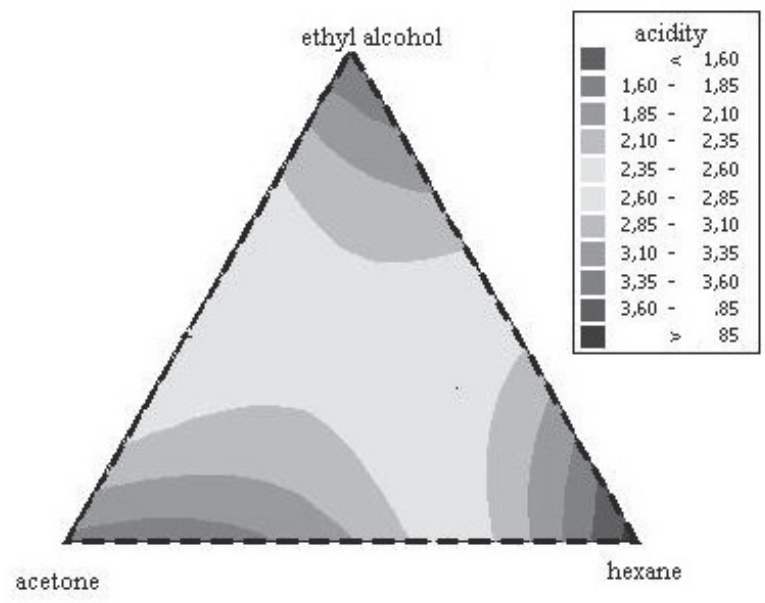

Figure 2

Contour line for acidity (expressed in \% of oleic acid) in different treatments. lower acidity value ( $0.27 \%$ of oleic acid) when pequi oil was obtained through a simplified smallscale process (using hot water).

Comparatively, an analysis of oil extraction from soy using various solvents (hexane, water and chloroform-methanol mixture at $2: 1 \mathrm{v} / \mathrm{v}$ ) revealed that the iodine value (133-136 $\mathrm{g} \mathrm{I}^{2} / 100 \mathrm{~g}$ of sample) and the saponification value (195-198 $\mathrm{mg}$ of $\mathrm{KOH} / \mathrm{g}$ of sample) did not differ significantly. Acid value, on the other hand, presented a higher value in the solvent mixture (1.3\% of oleic acid) in comparison to hexane and water, with $0.5 \%$ and $0.4 \%$ of oleic acid respectively (Kim et al., 1990.

As to the refractive index, no significant difference occurred among the different types of treatment, the average value being similar to the control sample that is 1.46 . This index can change not only as a function of the fatty acids (which may vary according to solvent type) but also with isomerization and conjugation which may result from the oil being badly handled (Elleuch et al., 2006). Silva et al. (1993) found a similar refractive index for pequi of 1.46 .

The fatty acid compositions of the pequi extract in each treatment are illustrated in Table 5 . We noted a similarity among the different types of treatment, as with the results obtained by Dunford and Zhang (2003) when extracting oil from wheat germ using different types of solvent: polar group (ethanol, isopropanol and acetone) and nonpolar group (n-hexane, high-purity hexane and isohexane). Pequi extract was found to contain more oleic acid (unsaturated fatty acid), also verified by Silva et al. (2003), and followed by palmitic acid (saturated fatty acid). Lima et al. (2007) observed that pequi oil is chiefly composed of unsaturated fatty acids, which attributes an excellent quality to the oil, especially for consumption.

Silva et al. (1993) points out the presence of oleic acid $(52 \%$ to $54 \%)$, palmitic acid (39\%), linoleic acid $(2 \%)$ and stearic acid (1\%) in pequi oil. According to the author, this composition is compatible with the epicutaneous natural coating, which justifies its use in cosmetic and pharmaceutical formulations.

The fatty acid composition in pequi oil, according to Lima et al. (2007), revealed a predominance of oleic, linoleic and palmitic acids and, to a lesser degree, the presence of stearic, linolenic, vaccenic, palmitoleic and arachidic acids. The values obtained reveal great disagreement with other works, leading the author to conclude that the oil had been adulterated, as, for instance, by the addition of soy oil.

Regarding carotenoid content, according to the contour lines illustrated in Figure 3 , obtained through a quadratic model where $\mathrm{R}^{2}$ is approximately $66 \%$, we note that the most significant effects were produced by the treatments with acetone (T2) and ethyl alcohol (T3), where higher values are verified, $300 \mu \mathrm{g} / \mathrm{g}$ and $296 \mu \mathrm{g} / \mathrm{g}$ respectively. The carotenoid content in the control sample was $202.72 \mu \mathrm{g} / \mathrm{g}$, followed by hexane (199 $\mu \mathrm{g} / \mathrm{g})$. Judging by the model equation, we verified 


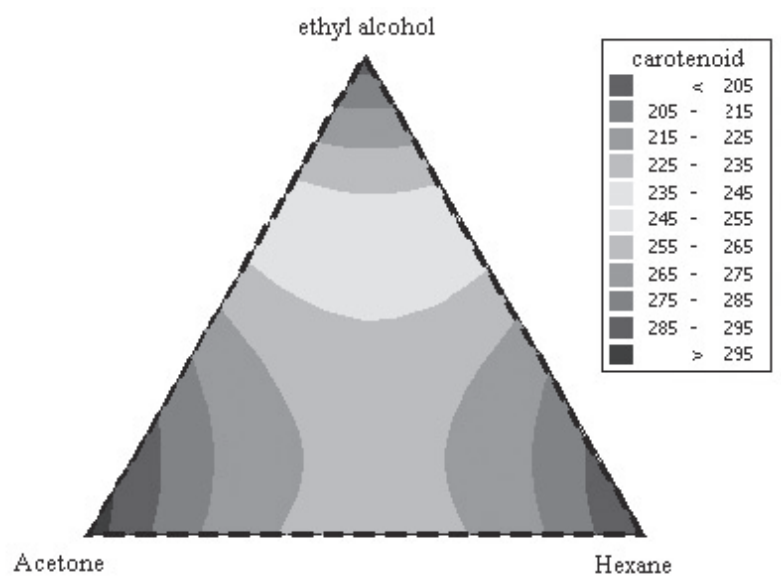

Figure 3

Contour line for carotenoid content $(\mathrm{mg} / \mathrm{g})$ in different treatments.

an antagonistic interaction between acetone and ethyl alcohol (coefficient $\alpha_{23}<0$ - Table 2).

In a study on carotenoid recovery from shrimp waste using various solvents, Sachindra et al. (2005) concluded that a higher content was obtained with an isopropanol and hexane mixture $(1: 1), 43.90 \mu \mathrm{g} / \mathrm{g}$ of residue. As for extracts obtained with other solvents (hexane, acetone and ethyl alcohol), it was verified, similarly to this experiment, that acetone presented a higher value $(40.6 \mu \mathrm{g} / \mathrm{g})$, followed by ethyl alcohol $(31.9 \mu \mathrm{g} / \mathrm{g})$ and hexane $(13.1 \mu \mathrm{g} / \mathrm{g})$. The value obtained for the hexaneacetone mixture $(1: 1)$ was $38.5 \mu \mathrm{g} / \mathrm{g}$. Based on these results, we can confirm that the carotenoid content was smaller when a non-polar solvent such as hexane was used.

Delgado-Vargus et al. (2000) reported on the advantages and disadvantages of using various organic solvents for the extraction of carotenoids and verified that the use of non-polar solvents is not recommended where humid samples are concerned.

De Ritter and Purcell (1981) verified that a full extraction of carotenoids should be done in lowhumidity samples by using a mixture of non-polar and slightly polar solvents. This fact is in agreement with the results obtained in this work, considering the yield obtained for the different mixtures, that is, hexane-acetone and hexane-ethyl alcohol.

\section{CONCLUSIONS}

Higher oil yields were obtained using acetone and hexane, especially their mixtures with ethyl alcohol. The different types of solvent did not influence the iodine value, saponification value and refractive index. A higher acidity value was verified in the extract using ethyl alcohol. Higher carotenoid contents were found in the extract using acetone and ethyl alcohol as pure solvents. The profile of fatty acids in the oil fraction of the extracts did not vary among the different types of solvents and their mixtures. As for the oil fraction, oleic acid was the dominant unsaturated fatty acid (53\%-54.8\%) and palmitic acid was the dominant saturated acid (39.6\%-41.5\%).

\section{ACKNOWLEDGMENTS}

We thank Embrapa Agroindústria de Alimentos for analysis of fatty acid composition on the oil, FAPEMIG (Fundação de Amparo à Pesquisa do Estado de Minas Gerais) and CAPES (Coordenação de Aperfeiçoamento de Pessoal de Nível Superior) for financial support.

\section{REFERENCES}

Abdulkarim SM, Long K, Lai OM, Muhammad SKS, Ghazali HM. 2005. Some physico-chemical properties of Moringa oleifera seed oil extracted using solvent and aqueous enzymatic methods. Food Chemistry. 93, 253-263.

Abu-Arabi MK, Allawzi MA, Al-Zoubi HS, Tamimi A. 2000. Extraction of jojoba oil by pressing and leaching. Chemical Engineering Journal. 76, 61-65.

AOCS. 1997. Official Methods and Recommended Practices of the American Oil Chemists' Society $\left(5^{\text {th }}\right.$ ed.). Champaign, IL:

AOCS. 1994. American Oil Chemists' Society. Official methods and recommended practices of the American Oil Chemists' Society. Champaign, Illinois: American Oil Chemists' Society, ed. D. Firestone.

Aquino LP, Corrêa JLG, Ferrua F Q, Borges SV. 2006. Influência dos métodos de secagem na extração do óleo de pequi e no teor de carotenóides. In: XXXII Congresso Brasileiro de Sistemas Particulados, 2006, Maringá. Anais, UEM. 1, 1-5.

Azevedo-Meleiro CH, Rodriguez-Amaya DB. 2004. Confirmation of the identify of the carotenoids of tropical fruits by HPLC-DAD and HPLC-MS. Journal of Food Composition and Analysis. 17, 385-396.

Chien JT, Hoff JE, Lee MJ, Lin HM, Chen YJ, Chen LF. 1990. Oil extraction of dried ground corn with ethanol. The Chemical Engineering Journal. 43, B103-B113.

Cornell JA. 2002. Experiments with mixtures: designs, models and the analysis of mixture data. New York: John Wiley and Sons, $3^{\text {rd }}$ edition.

Davies BH. 1976. Carotenoids. In: Goodwin, T. W. (Ed.). Chemistry and biochemistry of plant pigment. London: Academic. v. 2, 38-165.

Delgado-Vargus F, Jimenez AR, Peredes-Lopez O. 2000. Natural pigments: carotenoids, anthocyanins and betalains: characteristics, biosynthesis, preparation and stability. CRC Crit. Rev. Food Science Nutr. 40, 173-289.

De Ritter E, Purcell AE. 1981. Carotenoid analytical methods. In: Carotenoids, as colorants and Vitamin A precursos. Edited by: J. C. Bauernfeind. New York: Academic. 815-882.

Dunford NT, Zhang M. 2003. Pressurized solvent extraction of wheat germ oil. Food Research International, 36, 905-909.

Elleuch M, Besbes S, Roiseux O, Blecker C, Attia H. 2006. Quality characteristics of sesame seeds and by-products. Food Chemistry, 31, 115-124. 
Facioli NL, Gonçalves AG. 1998. Modificação por via enzimática da composição triglicerídica do óleo de piqui (Caryocar brasiliense, Camb.). Química Nova, 21, 16-19.

Franco D, Sineiro J, Pinelo M, Núñez J. 2007. Ethanolic extraction of Rosa rubiginosa soluble substances: oil solublility equilibria and kinetic studies. Journal of Food Engineering, 79, 150-157.

Freitas SP, Lago RCA. 2007. Equilibrium data for the extraction of coffee and Sunflower oils with ethanol. Brazilian Journal of Food Technology, 10, 220-224.

Garcia LMZ, de Oliveira TF, Soares PK, Bruns RE, Scarminio IS. 2010. Statistical mixture design Principal component determination of synergic solvent interactions for natural product extractions Chemometrics and Intelligent Laboratory Systems 103, 1-7.

Hartman L, Lago RCA. 1973. Rapid preparation of fatty acid methyl esters from lipids. Lab. Pract., 22, 245.

Kim IH, Yonn SH. 1990. Effect of extraction solvents on oxidative stability of crude soybean oil. The Journal of the American Oil Chemists' Society, 67, 165-167.

Lalas S, Tsaknis J. 2002. Characterization of Moringa oleifera Seed Oil Variety "Periyakulam 1" Journal of Composition and Analysis, 15, 65-77.
Lima A, Silva AMO, Trindade RA, Pavan-Torres R, Mancini-Filho J. 2007. Composição química e compostos bioativos presentes na polpa e na amêndoa do pequi (Caryocar brasiliense, Camb.). Revista Brasileira de Fruticultura, 29, 695-698.

Mani S, Jaya S, Vadivambal R. 2007. Optimization of solvent extraction of moringa (Moringa oleifera) seed kernel oil using response surface methodology. Bioproducts Processing, 85, 328-335.

Moreno AO., Dorantes L, Galindez J, Guzmán RL. 2003. Effect of different extraction methods on fatty acids, volatile compounds and physical and chemical properties of Avocado ( Persea Americana Mill.) oil. Journal Agricultural and Food Chemistry, 51, 2216-2221.

Sachindra NM, Bhaskar N, Mahendrakar NS. 2005. Recovery of carotenoids from shrimp waste in organic solvents. Waste Management, 1, 24-30.

Silva EC, Soares IC, Helou JH. 1993. Formulações emulsivas contendo óleo de "piqui" (Caryocar brasiliense, Camb.). Cosmetics And Toiletries, 5, 31.

StatSoft Inc (1999) Statistica for windows. 2300. Software.

Recibido: $13 / 9 / 10$

Aceptado: $9 / 11 / 10$ 